\title{
ARE WOMEN HUMAN? TAMPON TAXES AND THE SEMIOTICS OF EXCLUSION
}

\section{CARLA SPIVACK*}

By now, there is a robust body of scholarship critiquing the taxation of menstrual products from material, ${ }^{1}$ expressive, ${ }^{2}$ constitutional, ${ }^{3}$ and human rights perspectives. ${ }^{4}$ This literature highlights the issue of access to sanitary products in prisons, ${ }^{5}$ in secondary schools, ${ }^{6}$ and in poor countries. ${ }^{7}$ Invoking the expressive function of law, scholars have

\footnotetext{
* Oxford Research Professor of Law, Director of the Certificate in Estate Planning, and Director of the Center for Critical Trusts and Estates Studies, Oklahoma City University School of Law. Author of many articles about tax and trusts and estates, a book called The Smart Woman's Guide to Property Law, and coauthor of the West casebook Experiencing Trusts and Estates.
}

${ }^{1}$ See, e.g., Abigail Durkin, Profitable Menstruation: How the Cost of Feminine Hygiene Products Is a Battle against Reproductive Justice, 18 GEO. J. GENDER \& L. 131, 132 (2017) (arguing that "in order for women and girls to begin to attain Reproductive Justice, they must be empowered and provided with easy and affordable access to feminine hygiene products").

${ }^{2}$ See, e.g., Bridget J. Crawford \& Emily Gold Waldman, The Unconstitutional Tampon Tax, 53 U. Rich. L. REV. 439, 445 (2019) (arguing that the negative expressive impact of the tampon tax is far greater than any revenue these products could generate).

${ }^{3}$ See, e.g., Crawford \& Waldman, supra note 2, at 442 (arguing that "a tax on menstrual hygiene products ... amounts to an unconstitutional tax on women, because menstrual hygiene products are so inextricably linked to female biology").

${ }^{4}$ See, e.g., Bridget J. Crawford \& Carla Spivack, Tampon Taxes, Discrimination, and Human Rights, 2017 WIS. L. REV. 491, 494 (2017) (arguing that "the sales tax emerges as a key obstacle to gender equality and human rights. In the context of other sales taxes that fall disproportionately on women"); Margaret E. Johnson, Menstrual Justice, 53 U.C. DAvIs L. REV. 1, 8 (2019) (analyzing "how structural intersectionality can enhance the effectiveness of current menstrual legal reform and advocacy").

${ }^{5}$ Milea Moye, Female Inmates and Access to Feminine Hygiene Products, 29 Annals Health L. Advance DiRECTIVE 177, 178 (2020) (arguing that "access to feminine hygiene products is a basic right that female inmates have historically been deprived of, and therefore, legislation needs to be enacted to ensure that female inmates have access to feminine sanitary supplies").

${ }^{6}$ Johnson, supra note 4, at 7 (discussing lack of policy concern for "young menstruators").

${ }^{7}$ See generally Lia Kvatum, Menstrual Health Programs Need a New Focus in Developing World, Critic Says, WASH. Post (Jan. 13, 2019), https://www.washingtonpost.com/national/health-science/menstrualhealth-programs-need-a-new-focus-in-developing-world-critic-says/2019/01/11/3ce3e528-e8e0-11e8-bbdb72fdbf9d4fed_story.html [https://perma.cc/BHY8-VTGS]. 
noted how the tax signals to women that their basic physical and health needs are not human necessities that merit tax exemption - like say Viagra ${ }^{8}$ - but are rather luxuries that should be taxed - like cigarettes and alcohol. ${ }^{9}$ In this tax regime, human needs considered basic enough to merit tax relief - thinning hair, ${ }^{10}$ for example - are male needs. So what else is new? As Catherine Mackinnon asked, ironically, decades ago: Are women human? ${ }^{11}$

In this Article, I want to turn the expressive critique of tampon taxation in the direction of semiotics. ${ }^{12}$ Culture constitutes systems of signs through which we understand our world. These signs convey meaning though their difference from other signs, not through any intrinsic meaning. Tax law has its own signs. By imposing differing tax regimes on people and things, it tells us how to read them. For example, through differing taxation, it tells us what a family is (one organized around a formal marriage) and is not (networks of dependence organized around cohabitants), what work is (labor exchanged for goods) and is not (housework), etc. Taxes also tell us which goods are luxuries and which are necessities by imposing a luxury tax on certain items and exempting others.

\footnotetext{
${ }^{8}$ Jennifer Weiss-Wolf, U.S. Policymaking to Address Menstruation: Advancing an Equity Agenda, 25 WM. \& MARY J. RACE, GENDER \& SOC. JUST. 493, 500 (2019) (noting that “life-enhancing” drugs like Rogaine and Viagra also receive tax exemptions).
}

${ }^{9}$ Arielle Percival, California's Tampon Tax: Will the Third Time Be the Charm?, 51 U. PAC. L. Rev 429, 442 (2020) (noting that California's "sales tax exemption for menstrual products ... starts dissolving the argument that menstrual products are "luxuries," not "necessities").

${ }^{10}$ Annamarya Scaccia, In New York, Tampons Are Still Taxed -But Rogaine Isn't, VICE (Mar. 7, 2016), https://www.vice.com/en/article/vv5wpa/tampon-tax-lawsuit-new-york [https://perma.cc/QV6Z39T8] ("Yet the agency classifies Rogaine, dandruff shampoo, adult diapers, and incontinence pads-items also used by men — as 'medical supplies,' and thus tax exempt.").

${ }^{11}$ Catharine A. MacKinnon, Are Women Human? and Other International Dialogues 18-20, 160-68 (2006). Mackinnon asks this not-so-rhetorical question in the context of international human rights, which is the context for the tax question here, as well.

${ }^{12}$ Semiotics refers to the study of signs. Its foundational text is COURSE IN GENERAL LinGUiSTICS by Ferdinand de Saussure. Semiotics is the study of role of signs within society. Saussure's basic insight is that signs "like words or legal arguments take their meaning from their mutual relationships in a system of signification," not through a connection with any external, fixed referent. See Jack M. Balkin, The Hohfeldian Approach to Law and Semiotics, 44 U. MiAmi L. Rev. 1119, 1121 (1990). For an overview of semiotics in legal studies, see also J. M. Balkin, The Promise of Legal Semiotics, 69 Tex. L. REV. 1831 (1991). 
In their differential taxation of men's and women's physical needs, taxes on menstrual products tell us how to read women's bodies. They tell us that women's bodies deviate from the standard body, which is male. ${ }^{13}$ Like those bodies that the culture reads as disabled, female bodies require "add-ons," extra accommodations, to make them fit for public space - or any space at all, in fact. The tax code creates difference between female and male bodies by taxing women's physical necessities and not men's. It's not that anyone drafting a tax code consciously decided that no one really needed menstrual products, that they were a luxury that merited taxation. Layering taxes onto these products simply never caught anyone's attention; it never stood out as anomalous. It fit seamlessly into the word of read signs, signs that present the male body as baseline and female as baseline-plus.

I focus here on the way that the tax sign system works with the sign system of urban planning to exclude women from an equal place in public space. In doing so, I deploy the concept of semiotic systems to unify discussion of what are generally treated as discrete issues involving discrimination - taxes on menstruation products and the design of public space. This Article first historicizes women's exclusion from the public sphere and the anxiety about women's bodily fluids that became its materialized justification. I then show how menstrual taxation is part of a historically contingent and semiotically constructed gendering of public space. Then I suggest that a remedy to this broader problem of which the tampon tax is a part must disrupt the very nature of public space. To this end, I propose local initiatives for gender mainstreaming in city design and describe the successful implementation of such a project by the City of Vienna.

Free access to public space in all its forms is vital to full citizenship, full participation in community life, and full political participation. ${ }^{14}$ This access has traditionally been denied to women. No one in twenty-first century America would say that the law denies women access to public space, yet as a practical matter, public space is less accessible to women than it is to men. Indeed, that women lack the freedom men have to be in public

\footnotetext{
${ }^{13}$ For discussions of the male body as norm, see Erika Bachiochi, A Putative Right in Search of A Constitutional Justification: Understanding Planned Parenthood v. Casey's Equality Rationale and How It Undermines Women's Equality, 35 QuINNIPIAC L. REv. 593, 599-600 (2017) (critiquing "equality arguments for abortion as unjustly setting up the male body as the norm for legal equality"); Lisa C.

Ikemoto, Bioprivilege, 42 WASH. U. J.L. \& POL'y 61, 65 (2013) (noting the "pervasiveness of the normative male body" in medical school textbooks); Jessica L. Roberts, Accommodating the Female Body: A Disability Paradigm of Sex Discrimination, 79 U. CoLo. L. Rev. 1297, 1305 (2008) (observing that "the male ideal worker norm has led to work environments built exclusively for the male body").
}

${ }^{14}$ Sara K. Rankin, The Influence of Exile, 76 MD. L. REv. 4, 25 (2016) (noting the importance of shared public space for "diversity, difference, and democratic function"). 
space - in parking lots at night, hiking alone in the woods, or even taking walking tours of cities without public restrooms - is taken for granted, if not often articulated. But, as Holly Near sang, ironically, decades ago: "A lady don't go out alone at night." 15 This cultural drive to enclose women in the "private," domestic sphere and punish those who try to escape has a long history. ${ }^{16}$ But it has a history. It is not an innate feature of human life.

The early modern period saw a dramatic shrinkage in women's access to the public sphere and public space. This is not to say that the Middle Ages were a paradise for women, of course; menstruation aroused as much discomfort and revulsion as in later periods. But scholars of the Early Modern era in England have traced a narrowing of women's sphere from about the fifteenth to the eighteenth centuries. ${ }^{17}$ English society began to take on the contours of early industrial capitalism, ideologically separating the private domestic from the public productive sphere and relegating women to the former. ${ }^{18}$ The cultural reading of the female body that justified its containment was that of the "leaky" vessel, with its uncontrolled effusions of blood, breast milk, and urine. ${ }^{19}$ The bounded, controlled male body with its rightful place in public space emerged as the counterpoint to these female "leaky vessels." 20

\footnotetext{
${ }^{15}$ Holly Near, Fight Back, And Still We Sing: The Outspoken Collection Album (Calico Tracks Music 2002).

${ }^{16}$ The history of the relegation of women to the private sphere goes back a long way, but for coverage of the topic in the early modern period, see generally AMANDA FLATHER, GENDER AND SPACE IN EARLY MODERN ENGLAND (2007).

${ }^{17}$ Sara Mendelson \& Patricia Crawford, Women in EARly Modern England 1550-1720 (2000) (finding a shrinkage in women's public role in the period covered).

${ }^{18}$ See generally id. Of course, enclosure in the domestic sphere was never available to poor women, who worked in factories - but the ideology allowed them to receive less pay than men for the same work. See Alice Clark, The Working Life of Women in the Seventeenth Century (1919).

${ }^{19}$ Gail Kern Paster, Leaky Vessels: The Incontinent Women of City Comedy, 18 RenAissance Drama 43, 44 (1987) (discussing ways the culture of the period presented "the weaker vessel as leaky vessel").

${ }^{20} \mathrm{Id}$.
} 
The ideology of women's enclosure in the domestic sphere reached its height in the Victorian age, and that age also saw increasing challenges to this separation of spheres. ${ }^{21}$ Today, the law in many ways has dismantled women's limitations in the public realmemployment, education, sex-segregated institutions. But other sign systems, like the tampon tax, still signal the female body as an addition, an extra: Here, I focus on urban design.

The signs of public space still relegate the female body to the sidelines. They do this by constituting facilities for women as "add-ons": extras, implicit luxuries, just as taxation expresses this message about sanitary products. For example, as a physiological matter, women pee more often than men. Moreover, the fact that public urination is easier for men is unlikely to trigger much argument. Yet, almost no American city has public restrooms other than those in businesses open to the public. So, with respect to bodily functions, public space is already fully accessible to men. Yet, to make it equally accessible to women, planners would have to add a component. If women designed cities, I suggest, restrooms would be an unremarkable feature of city landscapes, like traffic lights. Because public space is coded male, however, they are an add-on and a luxury. This is the way the tax code treats tampons. Both differentiate between the baseline male body and the female body with its additional needs.

Safety in public is another example. Men can more easily walk to their cars in a dark parking lot than can women (although I do not mean to ignore that men can be crime victims as well). But the male-gendered design perspective that creates modern city streets does not see the need for crime-avoiding lighting or police callboxes. These are "added" features "to make the street safe for women," and they are often the result of pressure from women's groups or some particularly egregious crime against a woman.

Another point of contrast is the public availability of condoms. While condoms are available for sale in restrooms and bars, tampons are usually not. This is striking, since condoms allow sexual intercourse, which is not in any literal sense a biological need, tampons and pads serve a need that is literal and inescapable: the monthly menstrual cycle. That condoms - a discretionary consumer good - are available for sale in many locales that do not otherwise sell consumer goods (e.g., bars) but tampons-a necessityare not, mirrors, in public space, the treatment of Rogaine and Viagra versus tampons in the tax code.

\footnotetext{
${ }^{21}$ Danaya C. Wright, “Well-Behaved Women Don't Make History”: Rethinking English Family, Law, and History, 19 WIS. WOMEN's L.J. 211, 216 (2004) (noting both that women were relegated to a "constrained domestic sphere" while simultaneously "women ... wanted extensive reforms").
} 
Breastfeeding is another example of a need of the female body - and the infant, a category implicitly grouped with women. While almost every state has laws protecting women's right to breastfeed in public, ${ }^{22}$ many women report discomfort, embarrassment, and even harassment ${ }^{23}$ when trying to do so.

These examples make clear that the female body in public space is a disabled body, yet it does not fit into disability law. There are laws requiring accommodation in public space for people who can't access it the way others do: ramps for wheelchairs, walk light audio signals for people who navigate the world through sound, TDD phone lines for those who use sight. Like accommodations for the female body I have described, they are still "add-ons" - extras put in place, under the Americans with Disabilities Act, to comply with the law. In both cases, sign systems create difference between a "standard" body and a deviant body.

The way to change this is to change the very constitution of public space to make its baseline design accessible for and usable by women. In this way, the structure of urban space itself will allow for a rereading of the female body as normative, as opposed to deviant, because it will eliminate the meaning-producing difference between "public space" and "public space made safe for women." Women use walking routes more than men; they are more likely to be the parent taking children for walks, going to the playground, or doing errands by foot. ${ }^{24}$ While men are more likely to use public transit in a linear fashion, traveling to and from work, women more likely use it to go in different directions on the same trip to run errands. ${ }^{25}$ If public space accommodated women's habits, sidewalks would be wider, better lit, and more prevalent, and public transit might make more stops more frequently during work hours or have more busses and trains running local routes all day. If these changes are only occasional and ad hoc, they still read women as needing extras.

\footnotetext{
22 Meghan Boone, Lactation Law, 106 CAL. L. REv. 1827, 1842 (2018) (noting that "the vast majority of states--forty-seven--have affirmatively written the right to publicly breastfeed into state law").

${ }^{23}$ Lawrence M. Friedman \& Joanna L. Grossman, A Private Underworld: The Naked Body in Law and Society, 61 Buff. L. REv. 169, 196 (2013) (noting "recent incidents involv[ing] women who were thrown out of private establishments, or asked to cover up").

${ }^{24}$ Odette Chalaby, How Vienna Designed a City for Women, Apolitical (Aug. 23, 2017), https://apolitical.co/en/solution_article/vienna-designed-city-women [https://perma.cc/E5WVBVU5].

${ }^{25} \mathrm{Id}$.
} 
Some cities have redesigned themselves to accommodate the female half of their populations. Since the 1990s, the city of Vienna has implemented city planning to make the city accommodating to women. ${ }^{26}$ This is called gender mainstreaming. ${ }^{27}$ Several studies indicated that the city's infrastructure accommodated men and not women. ${ }^{28}$ So the city set out to change this. It carried out over sixty projects to make the city safer and more convenient for women. ${ }^{29}$ Adding footpaths and space for activities other than football to urban parks resulted in more girls using the spaces. ${ }^{30}$ Sidewalks were widened to ease use for pedestrians, and those with strollers, who are more often women than men. ${ }^{31}$ There have been twenty-six new street lighting projects, and additional outdoor seating has been installed. ${ }^{32} \mathrm{~A}$ successful pilot apartment complex designed by and for women has also led to gender analysis requirements for all bids for city social housing contracts. ${ }^{33}$ Vienna is an exception. Today, most public spaces still signal to women that their bodies are not standard and not accommodated and thus not welcome. Local campaigns for gender mainstreaming could be effective in changing this: Some cities in the United States have taken first steps. ${ }^{34}$ If women's bodies are to be read as standard and not deviant, sign systems must open up the possibility of this reading.

In this Article, I have tried to show that that taxes on menstrual products and the traditional design of urban public space both comprise a semiotics of exclusion. They operate in the semiotic realm in the same register as the occasional lactation room or the blue light callboxes in parking lots - a reminder that women need "extras" to navigate the world, even to maintain their bodies. Similarly, the wheelchair ramp or the buzzer on the

\footnotetext{
${ }^{26}$ Clare Foran, How to Design A City for Women, CityLAB (Sept. 16, 2013), http://www.citylab.com/commute/2013/09/how-design-city-women/6739/ [https://perma.cc/3TTK-C6NJ].

${ }^{27}$ Melissa Bellitto, Gender Mainstreaming in the United States: A New Vision of Equality, 22 UCLA WoMEN's L.J. 125 (2015).

${ }^{28} \mathrm{Id}$.

${ }^{29}$ Chalaby, supra note 24.

${ }^{30} \mathrm{Id}$.

${ }^{31} I d$.

${ }^{32} \mathrm{Id}$.

${ }^{33} \mathrm{Id}$.

${ }^{34}$ Bellito, supra note 27, at 144-46.
} 
occasional walk light "accommodate" people who are physically different. These accommodations for women in public space signal that women's bodily needs are not human needs, but something extra, beyond core "human needs"-in fact, that they are a luxury, not a need. This, in turn, suggests that any accommodation of women's bodies is not a human right, or a right of citizenship. Thinking about the semiotics of the tampon tax in connection to the semiotics of public space makes clear just how large the task is when the task is true equality. 